\title{
INIERE-SPACQ
}

\section{LINGUAGENS GEOGRÁFICAS E VIDEOCLIPE: Expressões geográficas em imagens}

\author{
Djeovani Roos \\ Mestre em Geografia pela Universidade Federal da Grande Dourados - UFGD. Membro do \\ Grupo de Pesquisa Linguagens Geográficas. \\ djeovani_roos@yahoo.com.br
}

\section{Cláudio Benito Oliveira Ferraz}

Doutor em Geografia pela Universidade de São Paulo - USP. Professor da Universidade Estadual Paulista Júlio de Mesquita Filho - FCT/UNESP/Presidente Prudente. Coordenador do Grupo de Pesquisa Linguagens Geográficas. cbenito2@yahoo.com.br

\section{RESUMO}

Saber se localizar e orientar são processos que utilizamos na nossa manifestação corporal cotidianamente, a geografia se encontra nessa espacialização da localização dos fenômenos. Geograficamente, o espaço é a forma com que os fenômenos expressam sua corporeidade espacial, de como se orientam e se localizam no mundo ali onde se encontram. Buscar outros referenciais de ver e ler as narrativas espaciais por meio do encontro entre geografia e demais linguagens produtoras de pensamentos espaciais torna-se necessário. Em tal desafio as nossas preocupações se compactuam com as atividades de estudos e extensão presentes no interior do Grupo de Pesquisa Linguagens Geográficas do qual participamos, assim como os objetivos do mesmo visam entender os professores de geografia como produtores de conhecimento geográfico, portanto, de não serem meros reprodutores de conteúdos ou metodologias já estabelecidas. Aí se encontra a força geográfica no encontro com as imagens e cabe ao professor explorá-las em seus sentidos criativos e criador de pensamento, não às usando como ilustração daquilo que já está definido. Assim, tomar a linguagem geográfica em seu sentido plural nos remete a pensar a dimensionalidade desse processo, das múltiplas formas nas divergências e convergências as quais se atribuem.

Palavras-chave: Ensino; Localização; Espacialidade; Videoclipe; Imagens.

\section{GEOGRAPHICAL LANGUAGES AND VIDEO CLIP: geographical expressions in pictures}

\begin{abstract}
Know if you locate and orient are processes that we use in our daily bodily manifestation, the geography is this spatialization of the location of the phenomena. Geographically, the space is the way the phenomena express their corporality, how to guide and are located in the world where there are. Get other benchmarks to see and read the spatial narrative through the meeting between geography and other spatial thoughts producing lenguages becomes necessary. In this challenge our concerns if agree with studies and extension activities present within the Group of Research Geographical Languages which took part, as well as the objectives of the same aim to understand the teachers of geography as producers of geographic knowledge, therefore, are not mere reproducers of contents or already established methodologies.
\end{abstract}


Linguagens geográficas e videoclipe: expressões geográficas em imagens Djeovani Roos; Cláudio Benito Oliveira Ferraz

There is geographical strength in meeting with the images and it is up to the teacher to exploit them in their creative senses and creator of thought, not using as an illustration of what is already defined. So, taking the geographical language plural sense leads us to think about the dimensionality of this process, the various ways in divergences and convergences which attribute.

Keywords: Education; Location; Spatiality; Video Clip; Images.

\title{
LENGUAS GEOGRÁFICAS Y VIDEOCLIP: expresiones geográficas en fotos
}

\section{RESUMEN}

Saber si ubique y oriente son los procesos que utilizamos en nuestra manifestación corporal diaria, la geografía es esta espacialización de la localización de los fenómenos. Geográficamente, el espacio es la forma de los fenómenos expresan su corporalidad, cómo guiar y se encuentran en el mundo donde se encuentran. Obtener otros puntos de referencia para ver y leer la narrativa espacial a través de la reunión entre la geografía y otros pensamientos espaciales producción de idiomas se convierte en necesaria. En este desafío nuestras preocupaciones si de acuerdo con estudios y actividades de extensión presentes dentro del grupo de investigación de lenguas geográficas que tomó parte, así como los objetivos de un mismo fin conocer los maestros de la geografía como productores de conocimientos geográficos, por lo tanto, no son meros reproductores de contenido o metodologías ya establecidas. Hay fuerza geográfica en reunión con las imágenes y es el maestro para explotarlos en sus sentidos creativos y creador del pensamiento, no usar como ilustración de lo que ya está definido. Así, tomando el sentido plural de la lengua geográfica nos lleva a pensar sobre la dimensionalidad de este proceso, las diferentes maneras en las divergencias y convergencias que atributo.

Palabras clave: Educación; Ubicación; Espacialidad; Videoclipe; Imágenes.

\section{INTRODUÇÃO}

\author{
"A vida existe de modo plural, não em um formato \\ definido. Ela é uma reta que passa por infinitos pontos \\ entre $A$ e $B$, e faz infinitas conexões de um lugar a outro". \\ (Rafael Trindade)
}

O mundo é fluxo, movimento e mudança. Quando a forma de ler o mundo é enrijecida, principalmente pelo pensamento arbóreo (DELEUZE; GUATTARI, 2011) do discurso científico maior, o institucionalizado e pautado na representação lógica da linguagem conceitual, reverbera uma imagem do mundo com que se tenta fixar o sentido de verdade, do mundo verdadeiro. Esse mundo acaba sendo a expressão lógica pela qual o sujeito pensante torna-o comunicável, logicamente explicado em seu processo de evolução temporal linear e sequencialmente uniformizante (passado-presente-futuro), assim como espacialmente extensivo e externo ao sujeito que o pensa. Um tempo que evoluiu numa 
Linguagens geográficas e videoclipe: expressões geográficas em imagens Djeovani Roos; Cláudio Benito Oliveira Ferraz

direção e um espaço que apenas é extensivo e sobre o qual as coisas se localizam (FERRAZ; NUNES, 2014; FERRAZ, 2012).

Um mundo, assim pensado, passa a ser vivenciado como se cada coisa fosse tão somente um objeto localizado num determinado ponto desse plano. Cada objeto, portanto, é passível de isolamento e pode ser analisado a partir da compreensão lógica da relação causa-efeito, a qual explica como era, como está e para onde evoluirá. Nessa perspectiva, o ser que pensa o objeto é quase um demiurgo, pois pelo seu intelecto lógico-racionalista é capaz de dizer a verdade de tudo que é o mundo, o que o torna capaz de controlar os processos que explicam como cada objeto é e de como se pode utilizá-lo em benefício próprio ou de grupos sociais que sentem necessidade de tal uso.

Mas o mundo é vida, não é algo em separado dessa, como uma base em que a vida se dá por meio dos objetos. O mundo é o imanente ao acontecer da vida nos múltiplos corpos a se diferenciarem numa constante mobilidade em aberto. Sem direção prévia, sem sentido determinado, a não ser de constantemente afirmar a vida como potência do próprio viver.

\footnotetext{
No debemos restringir una vida al simple momento em el cual la vida individual afronta la muerte universal. Una vida está en todas partes, en todos los momentos vividos por tal o cual sujeto viviente y que dan la medida de tal o cuales objetos experimentados: vida inmanente que implica los acontecimientos o singularidades que no hacen más que actualizarse em los sujetos y em los objetos. Esta vida indefinida no tiene en cuanto tal momentos [...]. No sobreviene ni sucede, sino que presena la inmensidad del tempo vacío donde se percebe el acontecimento aún futuro y ya ocorrido, em lo absoluto de uma conciencia inmedia (DELEUZE, 2007, p. 349).
}

Um mundo assim pensado passa a ser vida enquanto espacialidade imanente aos corpos, ou seja, lugares pensados/vivenciados enquanto corpo/mundo. Tal perspectiva desestabiliza as estruturas que se colocam como verdades essenciais e transcendentes ao mundo, as quais acreditam explicar como esse deve ser e se comportar de forma correta e normal, fixando o mundo em conceitos precisos, negando assim a dinâmica fugidia e subversiva do viver. Emana disso uma geografia capaz de apontar outros pensamentos espaciais, outras imagens da espacialidade até então não pensada (FERRAZ, 2013), mas sempre intensivamente vivenciada pelos e nos nossos corpos.

É aí que entendemos as inferências das linguagens geográficas, no devir de suas incongruências, buscando outras possibilidades para se pensar os fenômenos geográficos capaz de causar espanto/estranheza, para assim provocar o pensamento a pensar e se movimentar em outras direções. É nesse sentido que tal trabalho se desenha, ensejando 
Linguagens geográficas e videoclipe: expressões geográficas em imagens Djeovani Roos; Cláudio Benito Oliveira Ferraz

aqui não um amontoado de palavras referenciando um discurso já estabelecido verticalmente, mas sim podermos provocar outros pensamentos e outros sentidos de experimentações da vida.

O desafio se concentra no rascunhar outras possibilidades de leituras das narrativas que se transplantam no mundo, relacionando com os saberes geográficos e rasurar os limites que tentam fixar e uniformizar o sentido de ciência geográfica, forçando outras perspectivas possíveis a partir do encontro do discurso científico maior com as provocações instauradas pela força estética da linguagem imagética (OLIVEIRA JR., 2012). Esse foco é o que distingue e centraliza as análises neste trabalho, tendo os processos imagéticos como meio articuladores no desenvolvimento desse pensamento.

Para melhor pontuar nosso entendimento de linguagem geográfica, partamos de Douglas Santos (2007, p. 11), quando afirma que

[...] os fenômenos, para existirem, possuem uma dimensão espacial que influencia diretamente a sua existência - ou, em outras palavras, todas as coisas, quando mudam de lugar, mudam igualmente de significado para si e para as demais - isto é, todos os fenômenos possuem uma "geograficidade" e é dela que falamos quando queremos identificar o significado de cada coisa (ou processo) estar (ou se realizar) num dado lugar.

Todo e qualquer fenômeno possui sua dimensão espacial, a qual é o acontecer de cada fenômeno como lugar, ou seja, do encontro de um fenômeno com outros fenômenos, nesse jogo de forças entre esses corpos é que o lugar se constitui com dada forma espacial. Quando esse jogo de forças muda, os fenômenos passam a agenciar outros fenômenos, dando outro sentido para os seus processos de localização e orientação, constituindo assim outra forma espacial para o lugar, é outro lugar pois os corpos apresentam outra trama de forças que os constituem. Os significados de cada lugar, portanto, é a forma espacial com que os fenômenos expressam sua corporeidade espacial, de como se orientam e se localizam no mundo ali onde se encontram (FERRAZ; NUNES, 2014).

O que estamos querendo constatar aqui é essa tensão e encontro de forças dos fenômenos enquanto lugar - o espaço não está sendo visto aqui como uma base física sobre o qual se dá o lugar, pelo contrário, o espaço é uma das dimensões do lugar (SANTOS, 2007), e o lugar não se restringe a ser o local sobre o qual o fenômeno ocorre, mas é o acontecer das forças agenciadas e tensionadas nos encontros dos corpos (MASSEY, 2009; ESCOBAR, 2000) . Vejamos, esse já dado se desterritorializa a cada ação dos corpos, fazendo os lugares serem acontecimentos espaciais conforme esse encontro se dá. Nunca é algo fixo pelo desejo do conhecimento representacional definir e controlar o já 
Linguagens geográficas e videoclipe: expressões geográficas em imagens Djeovani Roos; Cláudio Benito Oliveira Ferraz

dado, num plano extensivo, mas sempre acontecendo enquanto intensividade da vida nos e pelos corpos, as linhas e forças que acontecem enquanto fenômenos corpóreos (UNO, 2012) - possibilitando outros sentidos espaciais.

Nesse aspecto, um corpo não se restringe a ser um fenômeno orgânico ou uma unidade de análise conceitual em si. Corpo é qualquer fenômeno em constante tensão entre as linhas que querem segmentar (endurecer e fixar em algo orgânico ou inorgânico) e as linhas de fuga nômades, fugidias e aleatórias, que sempre provocam derivas outras ao já dado e estabelecido (DELEUZE; GUATTARI, 2011). Os corpos, portanto, são tensões de linhas e forças sempre a se afetarem outros corpos, provocando tensões e agenciamentos (o pensamento, a sensação, o gesto, o desejo, uma rocha, um brilho de luz etc., são corpos, pois são forças e fenômenos que interferem em outras forças e fenômenos).

Nietzsche pensa o pensamento como corpo, e é ele quem nos diz que o "corpo é o fio condutor". Essas considerações são decisivas na nossa leitura do pensamento [...] pois ele reúne o orgânico e o inorgânico, o pensamento e a terra, os homens e os animais e é o meio (tal qual o fio de Ariadne) para se afirmar [...] da vontade de potência, pois é nela que se devem ler (e revelar) as noções - sempre flutuantes - de instintos, afetos e corpo (ESCOBAR, 2000, p. 93).

Essas considerações de Escobar sobre o pensamento do filósofo Friedrich Nietzsche, quanto à interação corpo/pensamento, são aqui reproduzidas para estabelecer nosso diagrama de como abordar o sentido da linguagem geográfica como forma de expressar o espaço como corpo, pensamento vivido e experimentado no próprio acontecer da vida. Ou seja, o "espaço é sempre corpo" e o "corpo pensa” (ESCOBAR, 2000, p. 31). Os corpos, portanto, são forças e linhas que constantemente se atualizam enquanto lugar de encontro dos corpos, aí a vida acontece em sua potência espacial.

O corpo é esse entrecruzamento do visível e do invisível, do dentro e do fora, do que se toca e do que é tocado. Ele não é uma coisa, nem uma ideia, mas o que faz existir uma coisa e uma ideia para nós. O corpo é essa espiral, essa circulação, esse enlaçamento, a dobra de meu interior e de meu exterior, entre o mundo e eu, a visibilidade e a opacidade (UNO, 2012, p. 58).

As palavras do filósofo japonês Kuniichi Uno complementam as de Carlos Escobar, são profundamente instigadoras do sentido, amplo e paradoxal, do corpo como espaço em que as diferenças se encontram e se multiplicam. Corpo como força, feixe de linhas a buscarem novos territórios de estabelecimento, ao mesmo tempo de constante desterritorialização de verdades e crenças dadas como certas ou únicas. 
Linguagens geográficas e videoclipe: expressões geográficas em imagens Djeovani Roos; Cláudio Benito Oliveira Ferraz

Diante do exposto, vamos delineando nosso plano de abordagem. O que destacamos disso é a questão do pensar. Pensar! Eis a prática emblemática da existência e da experiência humana. E a geografia não está desintegrada desse desafio; assim, para se construir um pensamento comprometido com a geograficidade se faz necessário a articulação com outros saberes produzidos, realçando a relação da geografia com outras construções do pensamento. Contudo, antes de passarmos à nossa experimentação de encontro de linguagens, cabe tecer alguns comentários sobre o contexto de referenciais com o qual territorializamos o sentido aqui de "linguagens geográficas".

\section{PONDERAÇÕES PARA OUTROS CAMINHOS POSSÍVEIS... RIZOMAS}

Buscar outros modos de ver e ler as narrativas espaciais por meio do encontro entre geografia e demais linguagens produtoras de pensamentos espaciais. Esse desafio não possui um método de como fazer, nem metodologias que definam os passos corretos, muito menos uma cartilha de como proceder. A questão é tomar a vida como força capaz de subverter as normas e processos ditos como corretos e mergulhar na diversidade de linguagens possíveis, buscando se localizar na trama linguagens e tentar agenciar enunciados em suas potências geográficas, sejam outras linguagens científicas, filosóficas e artísticas.

Tomar a linguagem geográfica em seu sentido plural nos remete a pensar a dimensionalidade desse processo, das suas múltiplas formas nas divergências e convergências as quais se atribuem. Esse deslocamento do pensamento congrega a ideia de rizoma, conceito este desenvolvido por Gilles Deleuze e Félix Guattari (2011) que resgatam da botânica o rizoma para aplicar na esfera das concepções filosóficas do conhecimento e expor num plano de imanência, nos acontecimentos e agenciamentos da vida, as linhas rizomáticas dos encontros da vida com a tênue relação do pensar. Metamorfoses que deslocam os sentidos e agenciam o pensamento, provocando-o a partir dos encontros com o fora, com o qual entra em contato e atualiza o virtualizado.

A questão que se coloca não é instigar um novo modelo ou um novo discurso que se sobreponha ao já estabelecido, como se pensar fosse apenas percorrer as trilhas já estabelecidas sobre um espaço fixo, mas sim, no nível das interações espaciais, se orientar num espaço liso, que se coloca nômade e imanente ao próprio pensar/viver, desafiante aos perigos e inesperados dos encontros dos múltiplos corpos que ali acontecem, estabelecendo o sentido rizomático de lugar. 
Assim, o rizoma possui o poder de emergir no espaço estriado em qualquer ponto. Além disso, porque não tem nenhuma organização centralizada, não pode ser erradicado completamente: ele tem várias linhas de fuga, por isso as forças que escapam sempre podem se restabelecer em outro lugar, para formar novos rizomas. O rizoma [...], como tal, é o conteúdo (superfície) para um espaço liso (BONTA; PROTEVI, 2004, p. 137. Tradução dos autores).

O rizoma é a força das linhas que se desdobram na contingencialidade desses encontros, configuram as relações desencadeadas enquanto espacialidade do lugar, ou seja, é o conteúdo do espaço liso, sua superfície mais profunda, não está sobre, mas é imanente aos encontros dos corpos/pensamentos.

Ao se dar essas condições o rizoma não se identifica numa sobreposição, mas ele articula os elos dos pontos na busca dos significados necessários para se fazer o múltiplo. O que pode se dar e perpetuar de qualquer ponto e seguir qualquer direção nos sentidos inesperados de orientação espacial, fugindo das estrias e caminhos já dados, deslizando em qualquer direção em que os agenciamentos dos corpos e enunciados tornam possível o mover, o fugir, o acontecer do movimento.

Rizoma distingue-se pelas suas ligações e articulações horizontalmente, que se espalham em linhas, propagando-se, promovendo o contato com outros elementos e produzindo encontros. Podendo se dissipar e brotar novamente em outro lugar, dividindo e subdividindo-se, criando outras direções. Concepção que se distingue do sentido arbóreo, de um ponto fixo verticalmente com suas ramificações, agenciando linhas de interação que se espalham sobre um plano e que não finca as suas raízes para se transformar num ponto imóvel.

\footnotetext{
A árvore ou a raiz inspiram uma triste imagem do pensamento que não para de imitar o múltiplo a partir de uma unidade superior, de centro ou de segmento [...]. Os sistemas arborescentes são sistemas hierárquicos que comportam centros de significância e de subjetivação, autômatos centrais como memórias organizadas (DELEUZE; GUATTARI, 2011, p. 35-36).
}

Nesse sentido que Deleuze e Guattari entendem o pensamento como uma força mais rizomática que arbórea "O pensamento não é arborescente e o cérebro não é uma matéria enraizada nem ramificada" (DELEUZE; GUATTARI, 2011, p. 34).

O pensamento arborescente encontra-se voltado para dimensão em que o pensar só se dá na condição de ser coerente com a lógica de discursos já concebidos e só assim ele se efetiva em sua função de explicar a realidade, para tal, seus processos de leitura se pautam na aplicação de um modelo lógico para resolver e solucionar todos os problemas; o fato é que essa forma de pensar se fundamenta num pensamento uniformizador, pautado na 
fixação de verdades essencializantes e passíveis de representação modelar; o pensamento se reduz a reproduzir opiniões enquanto representação de verdades uniformizadoras, acaba por se fechar em seus discursos estabelecidos pela hierarquia do campo organizador desses discursos (escola, academia, ordem política, instâncias religiosas etc.).

Isso se constitui numa imitação do múltiplo, como Deleuze \& Guattari (2011) apontam, pois o sentido de algo "novo" nessas condições se restringe ao já esperado, mero clichê de novidade, algo que apenas se desdobra linearmente do estruturado discursivamente, não se cria outras formas de pensar que escape, fuja das uniformizações. Já o rizoma opera pelos percursos desviantes, surgindo de qualquer ponto, inventando/criando/experimentando novas maneiras de pensar. É nesse sentido que as linhas de fuga se propagam, para criar outras condições de vivências que não se justifique pelas regras, normatizações estabelecidas e colocadas como "certas" ou "verdadeiras" que devem ser seguidas. Visto desta forma, Fernandes (2010, p. 118) destaca que decifrar "o processo de produção do espaço, apenas por meio de instrumentos da racionalidade objetiva e dogmatizante, não é suficiente”. É necessário que haja uma abertura para a diversidade da vida e suas diferenciações, observando as linhas explosivas que se destacam a cada encontro e espalham espacialmente várias outras linhas, para direções e sentidos até então não percebidos, pensados, trilhados.

Tal maneira de pensar o processo de produção espacial resulta numa ação rizomática que subverte o pensamento arborescente, o qual estrutura o sentido de produção espacial a partir de um processo de causa-efeito, numa linearidade em que os problemas que possam surgir de incompreensão ou dificuldade de controle dos fenômenos acabam sendo resolvidos com aplicação de um referencial metodológico mais eficiente, ou de uma tecnologia mais inovadora. Dessa forma, o espaço não é o acontecer da vida enquanto lugar do fenômeno, portanto, em aberto e em constante mobilidade e mudança, multiplicidade a se diferenciar, mas se restringe a ser a base física em que os fenômenos se localizam, os quais são exterioridades extensivas, passíveis de mensuração, controle ou eliminação.

Observando com Fernandes (2010, p. 125), os sentidos espaciais engendram-se pelos corpos (pensamentos, sentimentos e vivencias) imanentes a multiplicidade vivente da vida, instaurando as significações espaciais no instante que “[...] transgridem as fronteiras do comodismo, invadindo áreas indefinidas, provocando outros sons e ruídos, não só físicos, mas de valores, posturas e ideias", constituindo-se em algo diferente, outra visão do 
Linguagens geográficas e videoclipe: expressões geográficas em imagens Djeovani Roos; Cláudio Benito Oliveira Ferraz

pensamento em sua potência espacializante enquanto forma dos fenômenos no dinamismo do mundo.

O sentido de linguagens geográficas que estamos atribuindo a esse trabalho visa tal perspectiva dos corpos se encontrarem e assim o pensamento ser o próprio acontecer no mundo com o mundo (FERRAZ, 2013), isto é, a vida acontecendo no mundo e com o mundo da vida, o homem desenvolvendo as suas ações, enquanto dinâmica espacial do mundo, na integração dos elementos em que o mundo é produzido pelo mundo. São nessas possibilidades de pensar, como acontecimentos que se desdobram do encontro do pensar/mundo, que a linguagem geográfica se coloca em sua multiplicidade, em que a geografia aí se explicita.

A geografia aí é a contingencialidade espacializante das coisas e fenômenos acontecerem em diferentes direções e locais. A geografia é a capacidade de se criar pensamentos capazes de instaurar sentidos de orientação e localização do homem no contexto desse caos. Linguagem geográfica é exatamente essa tensão entre Terra e território, entre o estado das coisas e a capacidade de atualizar o sentido do mesmo, tornando possível sua leitura (FERRAZ, 2013, p. 3).

Dos encontros entre Terra e território, entre um estado de coisas ainda incompreendido e a possibilidade de atualizar o sentido desse fenômeno é que a geografia, enquanto linguagem científica, se coloca como um pensamento capaz de criar referenciais de localização e orientação para os corpos que ali se encontram. Tais encontros possibilitam a leitura geográfica dos fenômenos enquanto lugar, ou seja, a forma espacial dos fenômenos em constante mobilidade e transformação. Pois cada encontro dos corpos reverbera numa atualização das formas de todos os corpos envolvidos, redefinindo a paisagem dos mesmos enquanto lugar; nesse momento os sentidos são modificados, pois a forma espacial dos fenômenos se transforma, a paisagem passa a ser outra, resultando em outra ação a ser tomada ou em outro modo de agir mediante as circunstâncias em que se encontra. E essa maleabilidade espacial é que torna possível a leitura geográfica dos fenômenos.

A linguagem geográfica assim se territorializa enquanto pensamento, ela pode ser expressa de diferentes formas, podendo ser visual, sonora, simbólica, tátil, gestual, fotográfica, cartográfica etc., mas sempre foca na interpretação da forma espacial dos fenômenos vivenciados (SANTOS, 2007). Analisando as relações a partir desses elementos, pode-se apreender a geografia e entender esse campo do conhecimento como linguagem que se coloca em pluralidade, ou seja, linguagens geográficas. Dessa maneira, o conhecimento geográfico passa ser o agenciamento dessas diversas linguagens que 
Linguagens geográficas e videoclipe: expressões geográficas em imagens Djeovani Roos; Cláudio Benito Oliveira Ferraz

permitem estabelecer certos sentidos e referencias com que os corpos se localizam, se orientam, se territorializam em meio a mobilidade constante e diferenciadora de tudo. Em meio às forças rizomáticas... um pouco de possível se torna territorializável enquanto pensamento espacial.

\section{LINGUAGENS GEOGRÁFICAS: discurso científico e artístico a partir de um videoclipe}

Diante do exposto até agora, a partir de todas essas considerações mais conceituais e teóricas que desembocam no nosso entendimento de linguagem geográfica, colocamos o desafio de exercitar tal compreensão em um campo linguístico outro. Como podemos criar sentidos geográficos a partir do encontro de nosso corpo/pensamento científico com o corpo/pensamento de uma obra que se coloca no plano artístico? Vamos tentar experimentar pensar geograficamente a partir desse nosso encontro com o videoclipe da música "Imitation of Life" da banda R.E.M. (música do Álbum Reveal)"

Nosso foco será a força imagética do clipe dirigido por Garth Jennings, mas tendo claro que tal articulação imagética se coloca no agenciamento fundamentado na potência sonora da música e letra elaborada pela banda de rock. A opção por essa música/clipe se justifica por ser essa obra uma criação que nos afetou desde quando entramos em contato pela primeira vez com esse clipe, portanto, a escolha se deu por aspectos subjetivos de apreciação e prazer com que as imagens e o arranjo musical atravessaram de forma agradável nossa sensibilidade. Desta maneira, o que nos motivou foi à força imediata da obra de arte (Figura 1), da mesma maneira que outras músicas e clipes afetam a maioria dos apreciadores dessas linguagens.

\footnotetext{
${ }^{1}$ Música composta por Peter Buck, lançada no ano de 2001, encontra-se no Álbum Reveal da banda R.E.M., com duração de 3'57'. Disponível em: $<$ https://www.youtube.com/watch?v=0vqgdSsfqPs $>$.
} 


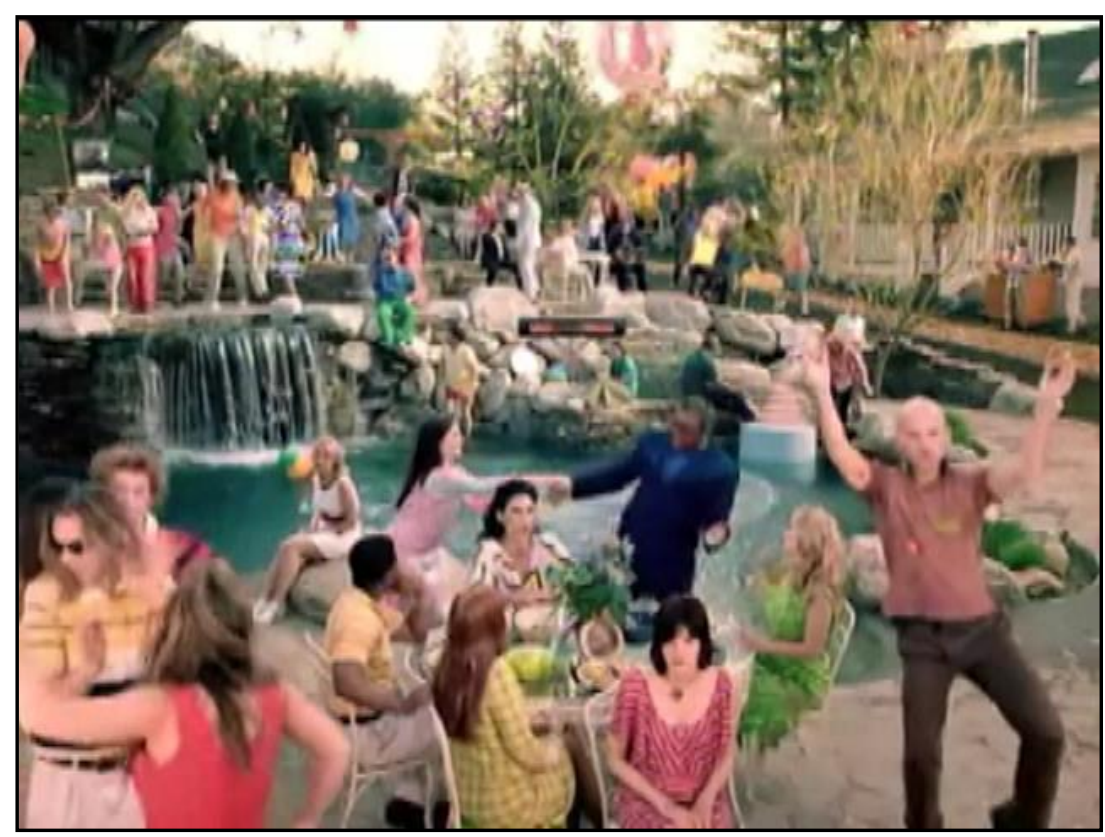

Figura 1 - "Encontros - Um Dia no Lago"

Frame do videoclipe "Imitation of Life", dirigido por Garth Jennings, 2001.

Diante de um motivo tão subjetivo, o desafio de pensar sobre algo que aparentemente não tinha um sentido geográfico pré-definido foi o elemento incentivador para experimentarmos novas possibilidades de leitura, ou seja, de buscar criar o sentido geográfico que virtualmente ali estava enquanto potência. Tal desafio compactuava com as preocupações que estimulam as atividades de estudos e extensão presentes no interior do Grupo de Pesquisa do qual participamos, assim como os objetivos do mesmo visam entender os professores de geografia como produtores de conhecimento geográfico, portanto, de não serem meros reprodutores de conteúdos ou metodologias já estabelecidas.

Quando passamos a debruçar com mais afinco sobre o referido videoclipe, aquele conjunto imagético-sonoro começou a se manifestar como uma paisagem. Começamos a identificar os sentidos territoriais do mesmo quando tal paisagem apontava o pensar no sentido da espacialidade dos lugares, evidenciando/revelando que as ações decorrem do processo de encontro dos corpos/pensamento e que estes produzem os efeitos que orientam os desdobramentos dos homens na busca dos sentidos de melhor se localizarem e se entenderem no contexto espacial em que se encontram.

Quando ouvimos a canção, a letra composta por Peter Buck nos chamou atenção, de forma geral, por abordar questões voltadas para um mundo de sonhos já préestabelecidos, mas que as condições de realizá-los são ilusórias, contudo, esse aspecto de uma vida sonhada, idealmente prazerosa é que fascina e atrai a todos para um mesmo lugar, qual seja, do hedonismo e conquistas fáceis. 
Linguagens geográficas e videoclipe: expressões geográficas em imagens Djeovani Roos; Cláudio Benito Oliveira Ferraz

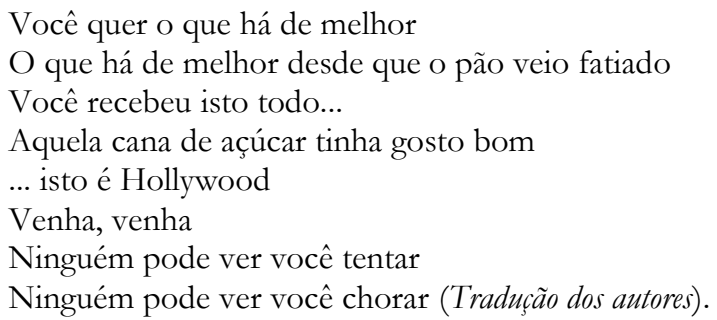

Interessante como o jogo de imagens, possibilitado pela letra, aponta para a ilusão de um mundo eternamente prazeroso e divertido, sem dificuldades ou esforços pessoais, na crença de basta querer o "que há de melhor" e ele se realizará sem esforços ou decepções, que tudo é doce como "cana de açúcar", pois tudo é fácil de se conseguir já que as coisas estão prontas e basta desejá-las para que tudo aconteça sem esforço algum, até o "pão veio fatiado"; contudo, essa ilusão se choca com o caos que é a vida, com seus acontecimentos contingenciais, múltiplos e rizomáticos, o que provoca constantes desprazeres, conflitos, tensões, desenganos e dores, daí a letra desta canção indicar o cinismo de termos de fingir nossa constante felicidade, de sempre sermos vencedores, para que ninguém possa "ver você tentar" nem poder "ver você chorar".

Isso talvez possa se relacionar com algum conteúdo geográfico (talvez de crítica aos valores ideológicos que aliena nosso modo de viver numa sociedade consumista e competitiva), mas nossa intenção não é tomar o clipe, no caso a letra da música, como ilustradora de algum conteúdo já estabelecido de antemão, melhor ainda, nossa opção não é focar no estudo da letra da música, apesar de ter ela como referência para discutir determinado aspecto de nossa análise, queremos pensar principalmente na articulação imagética apresentada no clipe como provocadora de novos pensares, capaz de nos instigar a criar outras imagens espaciais.

Imageticamente o clipe foi composto por uma sequência de tomadas em que de um plano geral, no qual vemos um grupo provável de turistas ao redor de um lago, com nítidas características de artificial (vide Figura 1), e conforme a música vai se desenvolvendo, do plano geral passamos, sem corte, para planos fechados a focalizarem alternadamente os vários grupos de turistas, com seus rostos e gestos, voltando a cada vez ao plano geral, num jogo de zoons em que as várias escalas (geral e fechada) se alternam, se repetem e se imbricam (ver Figura 2). 


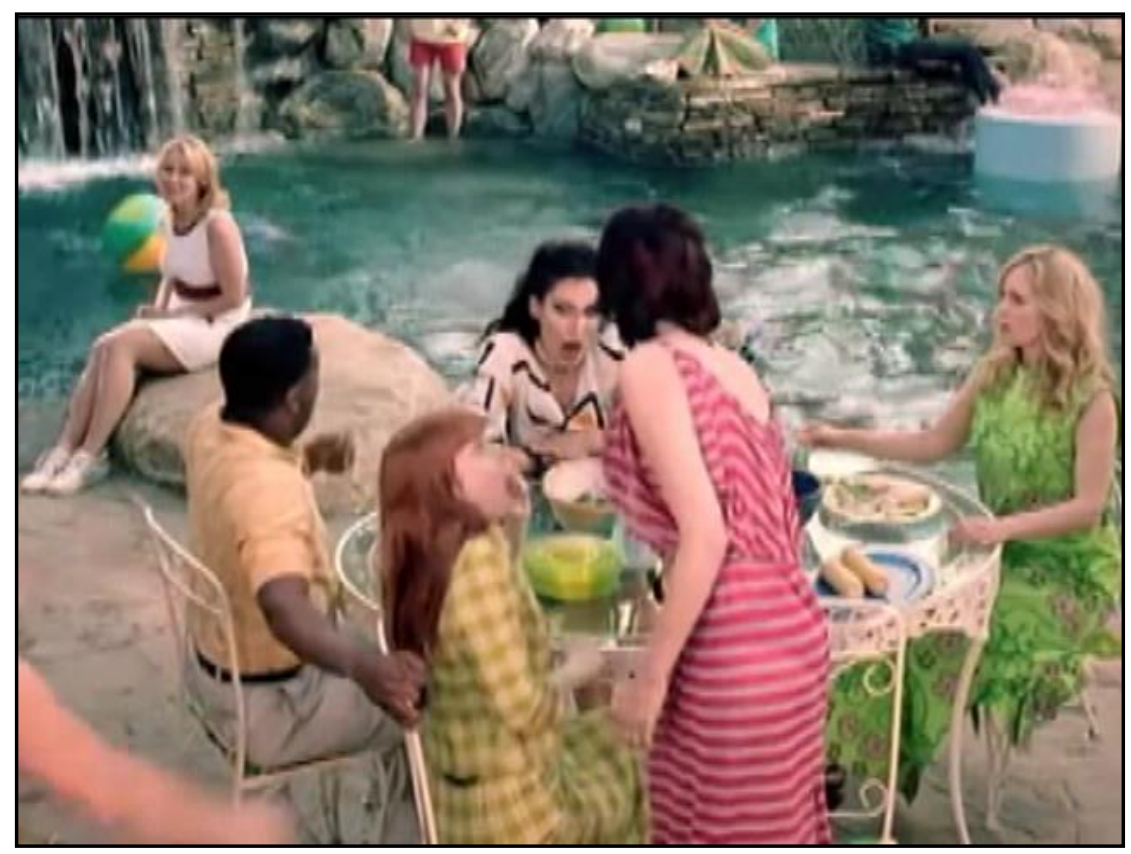

Figura 2 - "Afetações dos corpos"

Frame do videoclipe "Imitation of Life", dirigido por Garth Jennings, 2001.

As cores fortes, a iluminação dourada, como se fosse um dia quente de verão, as roupas de turistas, o verde das plantas, o azul do lago e do céu, assim como o bronzeado dos corpos, o mobiliário ao redor do pequeno lago, instigam em nosso imaginário, a partir de outras experiências que vivenciamos ou percebemos alhures, que aquele conjunto imagético se refere a uma dada paisagem, trata-se de algum parque temático em um período de férias, no qual se rompem com as obrigações do trabalho cotidiano e onde se pode encontrar o prazer e a alegria da natureza e do descanso. Quando assim regionalizamos o percebido, o fenômeno se territorializa em uma dada forma espacial. Percebemos os sentidos de usos territoriais ali localizados. Contudo, a paisagem assim identificada não se torna fixa, não se uniformiza nessa extensionalidade de usos e funções dos fenômenos naquele local; o clipe nos instiga a algo mais.

Naquela paisagem territorializada enquanto parque de lazer, no qual se encontra um aglomerado de pessoas num dia convidativo, ressaltam-se as diversas situações que desembocam do contato e das relações ali articuladas; os acontecimentos nesse espaço vão se dando, se repetindo e se modificando a cada vez que se repete, interferindo um acontecimento no outro. O vídeo, em compasso com a música, demonstra as ações que são tomadas e que no segundo seguinte, mediante outras situações, reverbera em outros contextos diferentemente daqueles conjugados pela ação inicial, evidenciando a ruptura das linearidades, estabelecendo que a imitação da vida ali não é mera representação, mas um decalque em que o mundo tende a acontecer diferente a cada repetição dos 
acontecimentos. A vida não é uma linha sentenciada sequencialmente, as relações humanas, o mundo, encontram-se em movimento, sempre se transformando.

A letra da música trata com ironia essa crença numa linearidade da vida, na qual tudo já se encontra delimitado, cabendo a nós apenas seguir as linhas estriadas desse espaço extensivo e nos adequarmos ao já dado para sermos felizes com os prazeres a nós destinados: "You've got it all, you've got it sized" ("Você tem tudo, você pegou tudo já medido"); tudo já está simetricamente composto, bastando nos adequarmos às simetrias num processo de completa imitação de vida, onde "ninguém pode te ver tentar" ("No one can see you try"). Um espaço estriado que só nos resta percorrer os caminhos já definidos, nos adequarmos a essa trilha e fingirmos que não tentamos ser algo diferente, pois nos acomodamos ao já dado. Esse tom irônico da música entra em contraste com as delimitações da vida, demonstrando que as suas manifestações não se dão num plano sequenciado de pensamento, mas que a vida é espaço liso, portanto, os desafios são inúmeros e que temos de tentar sobreviver, temos de saber melhor nos localizarmos para além do já imposto, do estabelecido como única verdade, caminho e direção.

Tal leitura fica patente quando vemos a montagem de imagens presentes no vídeo. Os diversos elementos constituidores do clipe, em suas diferenciações, significam um processo de desterritorialização das relações, uma fuga da "imitação de vida" enquanto ilusão de busca por eterno prazer, enquanto verdade já dada; ao mesmo tempo, no vídeo vemos essa imitação de forma concentrada num mesmo local, reverberando o aleatório e contingencial dos vários corpos que ali se encontram, ou seja, vidas interligadas pelas diferenças que se fazem presentes num mesmo e determinado lugar. Assim, podemos dizer que o espaço é uma construção de relações de corpos e fenômenos articuladas por linhas segmentares duras e flexíveis (DELEUZE \& GUATTARI, 2011), regidas por negociações que se dão na espacialidade, por políticas de convivência, onde as dimensões estão intrinsecamente interligadas, multiplicando-se infinitamente, levando a mudanças constantes do sentido de lugar. São linhas conectadas que formam o conjunto das relações, daí emana um diagrama, uma cartografia da vida.

Podemos observar, por exemplo, que o videoclipe em seus 3 minutos e 55 segundos de duração apresenta uma diversidade de pequenos acontecimentos vivenciados por cada grupo de corpos que se encontram ao redor do lago. Esses acontecimentos reproduzem fatos por nós já vivenciados ou percebidos ao longo de nossa vida (a raiva de uma moça em relação a arrogância de mulher que não para de falar; uma mulher que trai o marido, senhor mais velho com ar de burguês, com um trabalhador braçal; o encontro de 
amigos para fazer um churrasco; um homem visivelmente alcoolizado sendo puxado por sua amiga; a tristeza de uma moça solitária etc.).

Essas múltiplas histórias, que tem suas origens no que está no fora do ali percebido, acontecem como o agora espacial (MASSEY, 2009), mas elas são repetidas a cada frase da canção, num constante retroceder, como se estivesse retornando no tempo e depois volta a percorrer uma outra continuidade, ou seja, a cada repetição das ações, os elementos, de certa forma, sofrem mudanças, as relações já não são mais as mesmas que estavam se processando anteriormente. Numa temporalidade que não é linear nem circular, mas pura repetição do diferente (DELEUZE, s/d), força o pensamento a deixar de ser meramente arborescente, não se restringindo a identificar a relação lógica de causa-efeito de cada acontecimento, mas se coloca rizomaticamente a perceber a contingencialidade de como a cada repetição as interferências vão provocando pequenas mudanças na forma espacial do conjunto dos fenômenos ali percebido.

Podemos exemplificar a isso com a cena do homem a pegar fogo no churrasco com os amigos e cair no lago. Sua queda interfere no homem que está fazendo uma pirâmide de taças de champanhe, mas quando a cena é revertida, não existe a quebra da referida pirâmide e os amigos do churrasco continuam a se divertir. A sua queda se dá no mesmo instante em que uma moça, descontente e irritada com a constante fala e arrogância de uma mulher, num momento de fúria, se levanta e joga um copo d'água no rosto da senhora. No meio desse caos, um homem aproveita para colocar discretamente a mão no ombro de outra moça ao seu lado, segurando-a e envolvendo-a, demonstrando certo interesse por ela e essa atitude causa, ao mesmo tempo, certo estranhamento da moça, pois, talvez não esperasse por aquela situação, que só se efetivou por causa do copo d'água jogado no rosto da mulher, mas quando a cena é revertida, o copo não é jogado na cara da mulher, o homem não coloca a mão no ombro da moça e tudo mudou naquele local (vide Figura 2).

E em meio a todo esse contexto, há outros acontecimentos se fazendo presente naquela paisagem, como, por exemplo, pessoas dançando, se divertindo, cantando, outras conversando, algumas tristes e alheias ao seu entorno (ver Figura 3), isto é, os vários elementos e fenômenos que se articulam como a rotina da vida no que há de mais banal, mas na qual é onde surgem os sentimentos mais fortes de amor, ódio, paixão e desejo, linhas de força que intensificam a forma espacial dos fenômenos, que se manifestam como lugar (SANTOS, 2007). O que acontece num determinado local do parque muitas vezes não tem relação direta, enquanto extensão espacial, com outro fato que ocorre em outro local, mas pequenas mudanças em determinado acontecimento leva ao conjunto espacial 
Linguagens geográficas e videoclipe: expressões geográficas em imagens Djeovani Roos; Cláudio Benito Oliveira Ferraz

ser outro, pois são forças e linhas percebidas e vividas intensivamente, daí não se restringirem ao externo dos fenômenos, mas aos processos imanentes com que os corpos pensam seus acontecimentos em sua dinâmica espacial (FERRAZ, 2013).

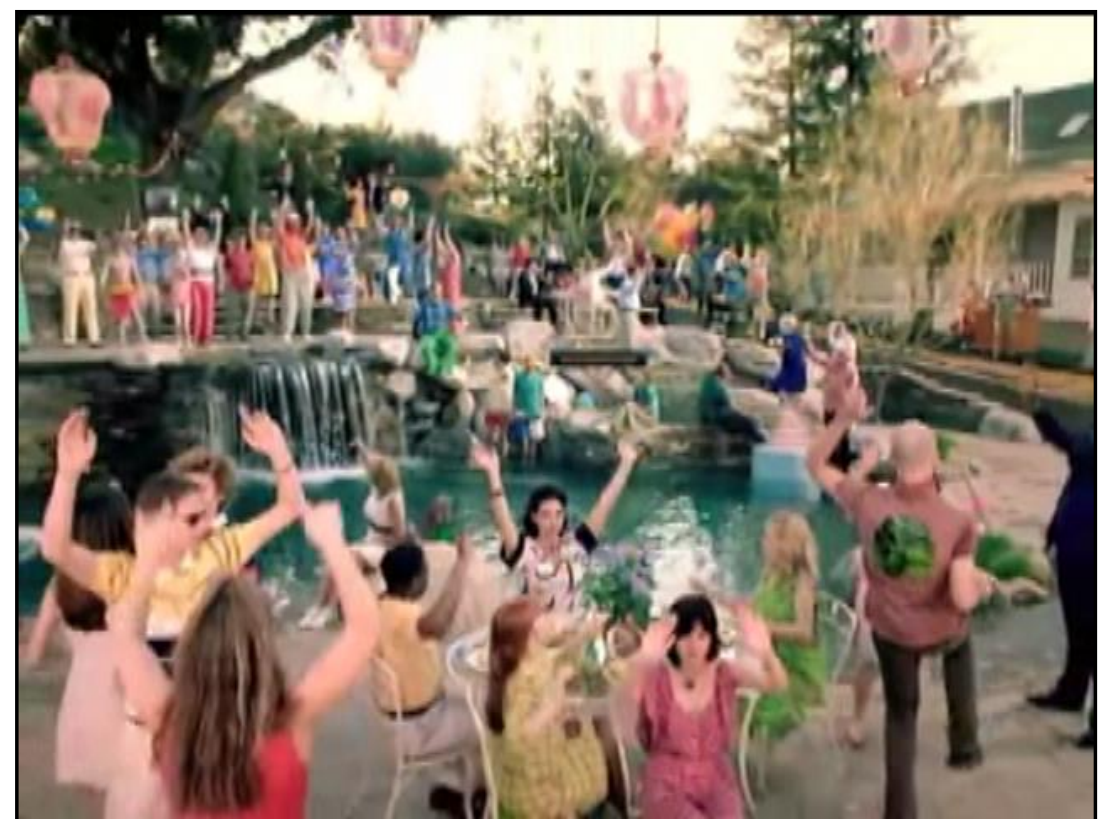

Figura 3-Close geral do clipe

Frame do videoclipe "Imitation of Life", dirigido por Garth Jennings, 2001.

Os acontecimentos vão tomando outros rumos, sentidos e significados, são constantemente negociados espacialmente conforme a intensividade dos mesmos se desdobra em novos deslocamentos, ações e pensamentos, fazendo com que o lugar apresente outra dinâmica, outra forma espacial. A paisagem do videoclipe, apesar do local ser o mesmo, enquanto extensão física e geométrica, sofre mudanças devido a intensividade da forma espacial dos fenômenos acontecer de outra maneira, ou seja, os fenômenos passam a ter outra forma espacial, territorializando os acontecimentos de forma diferenciada, por conseguinte, outra regionalização ali se manifesta. Conclui-se que o local é o mesmo mas o lugar, portanto, não é mais o mesmo conforme o encontro dos corpos contingencialmente acontece de outra maneira. O vídeo assim apresenta outra imagem espacial, outro sentido de ler e pensar a geografia da vida.

São nessas expressões cotidianas que o espaço é contextualizado e a espacialidade é construída. A vida se encontra nesse movimento, na dinâmica espacial do mundo, as relações entre as pessoas são articuladas por esses dinamismos que não se perduram linearmente. Como podemos observar no jogo de câmera do vídeo, ora focaliza o todo espacial envolvido, o conjunto dos acontecimentos no lugar em que os personagens estão, 
Linguagens geográficas e videoclipe: expressões geográficas em imagens Djeovani Roos; Cláudio Benito Oliveira Ferraz

ora focaliza as singularidades de determinados personagens, as suas expressões e ações desempenhadas espacialmente naquele determinado momento, destacando as políticas de negociação espacial que as relações humanas expressam, ou seja, a vida em sua contingencialidade dos acontecimentos.

Destaque para o título do clipe/música, se imita a vida, enquanto arte, é uma tentativa de apresentar a dinâmica múltipla e diferencial do viver, uma força rizomática que nunca é capturada por um pensamento lógico sequencialista, uniformizador de causas e efeitos, nunca se encerra naquilo que delimitamos como mundo verdadeiro, mas se encontra em aberto, em movimento, sempre um fenômeno a se transformar intensivamente no encontro dos corpos (DELEUZE; GUATTARI, 2011; DELEUZE, $\mathrm{s} / \mathrm{d})$.

A articulação de imagens presentes no videoclipe nos instiga a pensar a vida enquanto corpos que vão desenrolando os acontecimentos no encontro com o mundo, fazendo assim o mundo acontecer enquanto espaço pensado/vivido, como corporeidade, como forma dos fenômenos (UNO, 2012). O vídeo permite outras perspectivas e imagens de pensamentos espaciais a partir da percepção que esses encontros são rizomáticos, pois nada garante que um gesto aqui se desdobra numa ação acolá, pois não há linearidade lógica, mas de contingencialidade de encontros, do que pode afetar tal corpo ou não, daquilo que externo com o que é interno ao corpo.

O corpo é essa espiral, essa circulação, esse enlaçamento, a dobra de meu interior e de meu exterior, entre o mundo e eu, a visibilidade e a opacidade, o quiasma [...] definindo-o como qualquer coisa que dá a base do ser sensível no mundo (UNO, 2012, p. 58).

Isso coloca para a geografia a possibilidade de atribuir outros pensamentos de entendimento espacial na produção da vida, a qual se dá em determinado local e é orientada pelas forças e tensões das linhas que configuram o lugar, dando outras dimensionalidades ao pensamento para pensar os arranjos que significam e alimentam as direções espaciais das relações homem/mundo e vice-versa, não contém nem ponto de início e nem ponto final, mas um constante fazer-se no movimento da vida. Doreen Massey (2009, p. 89) nos esclarece que a questão é "[...] compreender o espaço como uma produção aberta contínua", enquanto uma multiplicidade de acontecimentos.

O vídeo em questão nos forçou a pensar nesse sentido, pois as diversas ações que ocorrem num mesmo ambiente ali são apresentadas e repetidas; essas situações podem mutuamente se afetarem, ou então se ignorarem, mas como são singularidades corpóreas 
que se relacionam, a cada mudança no encontro o conjunto todo muda, ou seja, a forma espacial do lugar passa a ser outro.

Por isso que entendemos o local ser o mesmo (pois o local está na ordem do extensivo, do passível de ser mensurado, geometricamente delimitado, é um espaço estriado e fixado, mas o lugar mudou. O lugar está para a potência do movimento, é da ordem do espaço liso, resultado de forças intensivas e rizomáticas, fazendo com que a cada encontro dos corpos a forma espacial do fenômeno se transforme, ou seja, que a paisagem sofreu transformações a partir das contingencialidades rizomáticas dos encontros ali ocorridos, pois houve novas territorializações de relações, uma nova regionalização de sentidos e usos dos fenômenos aconteceram (SANTOS, 2007; FERRAZ, 2013).

Quando cada conjunto de pessoas presentes naquele ambiente fica a repetir seus movimentos, revertendo-os por um efeito de edição do diretor do vídeo, instaurando outras possibilidades deles ocorrerem em situações diferentes, afetando aos demais de forma direta ou não, temos aí uma "imitação da vida", não uma representação da vida, mas uma espécie de decalque (DELEUZE, 2011) a nos forçar a pensar no que ali estamos encontrando de inusitado e de comum em nossas vidas. A multiplicidade de histórias que até ali acontecem e se diferenciam a cada repetição leva-nos a pensar outros sentidos de geografia (MASSEY, 2009). Uma linguagem geográfica que não fica circunscrita a um espaço estriado do conhecimento científico institucionalizado, mas que deslize em um espaço liso e aberto às múltiplas direções futuras enquanto nosso presente possível.

\section{PONDERAÇÕES FINAIS}

A linguagem científica que buscamos intentar nessa reflexão visa à construção de uma linguagem nos seus encontros com outras linguagens, com o que provoca de rasuras e derivas em si e nas outras, fazendo do conhecimento um acontecimento (SANTOS, 2004). Linguagem assim não se reduz a representar ou determinar o mundo, não é só palavra que ordena e significa o mundo, mas é matéria e conteúdo de expressão, maneiras do mundo enquanto pensamento se expressar (DELEUZE; GUATTARI, 2011). Vislumbrando assim o sentido plural dessa linguagem científica, as linguagens geográficas na construção e agenciamento de outras narrativas. Essas linguagens são apreendidas num sentido de multiplicidade, isto é, que o caminho dos saberes não se agarre a uma única forma de linguagem, em uma única estrutura, mas que estabeleça intercessores com as linguagens possíveis na constituição do conhecimento, podendo assim potencializá-lo. 
Linguagens geográficas e videoclipe: expressões geográficas em imagens Djeovani Roos; Cláudio Benito Oliveira Ferraz

A questão não é desfazer uma linguagem com a substituição por outra, como se fosse uma troca de métodos, de uma linguagem mais "viável" ou "apta" ao discurso em detrimento da outra, não. A questão é mais ampla, é identificar as outras linguagens possíveis que potencialize o exercício dos saberes geográficos. É oxigenar o pensamento para não mais reproduzir os discursos, mas produzir efeitos que possibilitem a geografia intentar compreender o espaço em suas multiplicidades. Permitindo que se manifestem as geografias possíveis na relação com outras áreas do conhecimento, como na inter-relação com as artes, as imagens e os sons que visamos nesse trabalho. Criando assim linhas de fuga, geografias que possibilitem percorrer outras direções e sentidos de orientação e localização do homem no mundo e com o mundo.

Essas geografias menores (OLIVEIRA JR., 2009; 2010) podem ser identificadas e produzidas na relação com a literatura, a poesia, a arte, o cinema, a música, o vídeo etc. Essas articulações possibilitam a criação de referenciais espaciais, colocando em evidência o pensamento para pensar outros processos e manifestações. Estamos querendo vislumbrar aqui é que...

Diante dos limites do discurso institucionalizado, o mundo força essas margens discursivas, cobrando de outros saberes, notadamente os artísticos, outras imagens e sentidos de se pensar e viver o espaço. Daí se criar geografias menores, subversivas, marginais, clandestinas e instauradoras de outras linguagens geográficas. Quando isso acontece, o homem tem outras possibilidades de se orientar e se localizar no mundo a partir do lugar em que a vida acontece (FERRAZ, 2013, p. 2).

As linhas de fuga das concepções generalizantes e uniformizantes do espaço, características da linguagem científica predominante da geografia (da geografia maior), inala-se a criatividade, isto é, promove a criação, a invenção na elaboração de novos pensamentos, novas formas de expressar, de vivenciar, para romper com os limites fixos que a linguagem geográfica institucional define como território, região, ou uma paisagem, instaurando deslimites no olhar geográfico, possibilitando, assim, instigar outros pensamentos dos sentidos espaciais (derivando sentidos minoritários dessa geografia maior). Potencializando as geografias em movimento instauradas pelas turbulências necessárias para inventar, criar palavras e sentidos, as quais provocam o exercício de forçar o pensamento a pensar outros sentidos espaciais, atualizando outras linguagens geográficas (FERRAZ, 2012).

Expressando, dessa forma, sentidos diferenciados que se desdobram da multiplicidade das linguagens menores, que possibilitam tensionar - no sentido de abalar, desestabilizar - as estruturas da linguagem ordenadora no encontro de forças que 
Linguagens geográficas e videoclipe: expressões geográficas em imagens Djeovani Roos; Cláudio Benito Oliveira Ferraz

desalinham os trilhos, desenclausurando, assim, a linguagem geográfica de uma ideia de verdade transcendental ao mundo (FERRAZ, 2013), para entender os acontecimentos da vida em seu pleno ato e gozo do viver, em todas as suas relutâncias e aflições, possibilitando melhor se orientarem e se localizarem em meio ao caos da vida.

Foi essa a intenção de experimentar outros pensamentos e imagens espaciais a partir de nosso encontro com o videoclipe da música "Imitation of Life". De algo que aparentemente não tinha nada de consagrado como conteúdo geográfico, passamos a identificar uma forma paisagística que delineava outras possibilidades. A princípio a questão da espetacularização da vida, com as ilusões do consumismo e do hedonismo constante do mundo capitalista, passou a ser uma possibilidade de aproximação, mas depois, fomos percebendo que os elementos imagéticos apresentados no clipe apontavam para outra territorialização desse vazio da vida. A questão deixou de ser a identificação de algo já definido a priori como geográfico para ser a busca por outros sentidos e imagens espaciais que o clipe podia provocar, ou no mínimo potencializar.

Adentramos aquelas imagens e fomos sendo afetados por aquele bloco de sensações estéticas. Não só a letra, ou a melodia, mas o conjunto imagético-sonoro reverberou em nós outras possibilidades de encontro com a linguagem científica da geografia. De uma linguagem maior, institucionalizada, começou a derivar sentidos minoritários a partir do encontro com aquele jogo de imagens editadas, focadas em determinados ângulos e conjunto de acontecimentos. Passamos a pensar outra regionalização dos acontecimentos que ali se repetiam, voltavam e se imbricavam, daí outra perspectiva de tempo e de espaço se desdobrou, de uma diversidade de histórias que ali aconteciam num espaço que se colocava como o agora em sua multiplicidade intensiva e dinâmica (MASSEY, 2009).

O rizoma se fez presente, rasurando o pensamento arbóreo e representacional que se coloca como o único possível para a linguagem científica da geografia, permitindo derivar desse discurso maior linha de fuga em suas forças minoritárias. Outros sentidos para o pensamento científico se colocou a partir do encontro com aquela linguagem artística.

O pensamento científico, ao considerar apenas um padrão lógico de racionalidade instrumental, tomando-o como o único entendimento possível da realidade, despreza, portanto, uma série de elementos essenciais para a leitura do espaço, como as sensações, emoções, o cotidiano, a subjetividade, a fantasia, o imaginário, o místico e aleatoriedade de quem vivencia esse espaço. Por mais que se procure adequar o real à linguagem científica hegemonicamente institucionalizada, a dinâmica das relações espaciais, as quais se presentificam e se manifestam na realidade diversa do cotidiano dos indivíduos e sociedades, 
Linguagens geográficas e videoclipe: expressões geográficas em imagens Djeovani Roos; Cláudio Benito Oliveira Ferraz

não é tangível a um único padrão lógico-formal de expressão gramatical e fundamento matemático. Tal fato evidencia os limites deste modelo de conhecimento (FERNANDES, 2010, p. 118-119).

São diante desses limites que as linguagens geográficas, inseridas numa perspectiva rizomática, nômade, convergem às possibilidades de friccionar o pensamento para abranger as multiplicidades recorrentes no mundo, das instantaneidades espaciais que se produz a todo o momento, da mobilidade humana no espaço. Das configurações espaciais que são organizadas pela política da espacialidade. Direcionando e relacionando o pensamento geográfico em que usufrua das diversidades existentes e das experiências vividas para situarse no lugar, isto é, localizar-se, orientar-se espacialmente, saber onde está, pra onde vai, o que se deseja na contingencialidade do espaço.

Isso não significa deixarmos de lado o pensamento maior, representacional e arbóreo da geografia, mas podemos entender que outros pensamentos minoritários dele derivam com suas forças subversivas e potencializadoras de novos sentidos espaciais e temporais. O encontro com o referido clipe, com seu agenciamento de linguagens artísticas (poesia, melodia, imagens videográficas e computadorizadas etc.), é que tornou possível a territorialização em nosso pensar científico outras imagens de tempo e espaço.

Do painel eletrônico presente na abertura do clipe até o bolo de aniversário com a menina suspensa em primeiro plano com os confetes subindo ao fundo, ao invés de descer, o clipe instiga a essa interseção entre linguagens artísticas e científicas na configuração de se pensar a geografia como um conhecimento que não se restringe a ser um mero desdobrar de um tempo linear e progressista; a tecnologização da vida, a demarcar e estriar o que devemos ver e ouvir (o painel eletrônico no meio do lago é o elemento delimitador dessa ordem espacial, mas é também o potencializador crítico dessa mesma ordem, uma autocrítica que o próprio clipe significa sua função em aberto), é rasurada com a caoticidade dos pequenos dramas e banalidades dos vários corpos humanos a darem dinâmica a aquele local, fazendo-o se configurar como um lugar, a forma espacial do viver que ali acontece, a vida como futuro que não se restringe ao desenvolvimento linear do corpo da criança ao final do vídeo, mas como os confetes sobem, negando o destino gravitacional dos corpos, o futuro é um repetir de forças contingenciais, com a potencialidade de sair das estrias do espaço tecnologizado e estabelecer rizomaticamente direções incertas.

Essas imagens e elementos presentes no videoclipe nos forçam a pensar o espaço como uma construção das multiplicidades do aqui e agora, das múltiplas trajetórias (MASSEY, 2009) que desembocam em linhas de fricção e se abrem rizomaticamente, se 
constituindo constantemente pelas forças que entram em contato e se dobram na sua produção, mobilizando e articulando o pensamento, tornando-o uma manifestação em movimento - corporalmente -, instaurando outras perspectivas de localização e reorientando as direções possíveis.

Dialogando com Santos (2010, p. 193), constatamos que "Todos devemos oferecer aos nossos jovens e às nossas crianças, a possibilidade da imaginação, a possibilidade de olhar o mundo sob diferentes focos ou perspectivas". E o que é o espaço e o tempo senão o encontro dos corpos e acontecimentos no mundo? As suas relações. O pensar que pensa o peso da vida enquanto encontro de corpos, dobras, encontros e tensões entre as forças internas e externas do/no mundo/corpo/pensamento, forças imanentes, uma vida (DELEUZE, 2007).

A questão é propulsionar derivas nas lógicas geográficas institucionalizadas, formalizadas, desvendar fendas, descobrir rupturas para impulsionar outras perspectivas de se pensar os fenômenos geográficos e suas espacialidades. Compreendendo as geograficidades do mundo e o sentido de estar nele. Ou seja, é a busca de orientação e localização do homem no mundo, assumindo as suas potencialidades e limites, pois, “[...] os sentidos que damos ao tempo e ao espaço são cruciais para a nossa percepção do que somos no mundo" (FERRAZ, 2010, p. 26).

O que se pontuou e ficou em jogo reflexivo neste trabalho são as questões das linguagens geográficas - relacionadas aqui na análise de um videoclipe - e as possibilidades de outros horizontes de pensamento nesse âmbito, que são ou podem ser evidenciados nas relações e na dinâmica espacial e temporal do mundo. Em que os acontecimentos da vida, a mobilidade humana e sua manifestação permeiam-se nos contextos das linguagens geográficas. Articulando essas possibilidades com a utilização das imagens e sons, despertadas e interagidas aqui pelo videoclipe, no processo de construção do conhecimento e de atualização do pensamento geográfico. Imitação da vida como criação de outros sentidos e imagens espaciais.

\section{REFERÊNCIAS}

DELEUZE, Gilles. Dos regímenes de locos - textos y entrevistas (1975-1995). Valência (ES): Pre-Textos, 2007.

DELEUZE, Gilles. Nietzsche e a filosofia. Lisboa: Rés editora, s/d. 
Linguagens geográficas e videoclipe: expressões geográficas em imagens Djeovani Roos; Cláudio Benito Oliveira Ferraz

DELEUZE, Gilles. \& GUATTARI, Félix. Mil platôs: capitalismos e esquizofrenia. Vol. 1. São Paulo: Editora 34, 2011.

ESCOBAR, Carlos H. Nietzsche... (dos “companheiros”). Rio de Janeiro: 7Letras, 2000.

FERNANDES, Anedmafer M. Paisagem sonora e o ensino de geografia: quatro minutos e trinta e três segundos de leitura do espaço. Revista Entre-Lugar, Dourados/MS, ano 1, n. 1, p. 113-132, 2010.

FERRAZ, Cláudio Benito O.; NUNES, Flaviana G. O horizonte não é linear: paisagem e espaço na Perspectiva Audiovisual Linear de Anton Corbijn. Revista Ateliê Geográfico, Goiânia/GO, v. $8, \quad$ n. 1, p. 166-180, 2014. Disponível em: < https://revistas.ufg.br/atelie/article/view/28153 >. Acesso em: 25 jun. 2016.

FERRAZ, Cláudio Benito O. Entre-Lugar: apresentação. Revista Entre-Lugar, Dourados/MS, ano 1, n. 1, p. 15-31, 2010. Disponível em: <https://goo.gl/zDqAXs $>$. Acesso em: 22 de jun. 2016.

FERRAZ, Cláudio Benito O. Geografia: o olhar e a imagem pictórica. Revista ProPosições, Campinas/SP, v. 20, n. 3 (60), p. 29-41, 2009.

FERRAZ, Cláudio Benito O. Imagem e geografia: considerações a partir da linguagem cinematográfica. Revista Espaço \& Geografia, v. 15, n. 2, p. 357-384, 2012. Disponível em: < https://goo.gl/e2Yg2d >. Acesso em: 20 maio 2016.

FERRAZ, Cláudio Benito O. Linguagens geográficas: outros possíveis minoritários. In: ENCONTRO SUL-MATO-GROSSENSE DE GEÓGRAFOS e V EREGEO ENCONTRO REGIONAL DE GEOGRAFIA, 21., 2013, Dourados. Anais eletrônicos do XXI ENSUL. Dourados/MS: UFGD - Universidade Federal da Grande Dourados, 2013.

KHOURI, Mauro Michel el. Rizoma e educação: contribuições de Deleuze e Guattari. In: ENCONTRO NACIONAL DA ABRAPSO, 15., 2009, Maceió. Anais eletrônicos do XV ENABRAPSO, Maceió/AL: Associação Brasileira de Psicologia Social, 2009. Disponível em: $<$ http://www.abrapso.org.br/siteprincipal/images/Anais XVENABRAPSO/198.\%20 rizoma $\% 20 \mathrm{e} \% 20$ educa $\%$ C7\% $\%$ C3o.pdf $>$. Acesso em: 25 mar. 2016.

MASSEY, Doreen. Pelo espaço: uma nova política da espacialidade. 2. ed. Rio de Janeiro: Bertrand Brasil, 2009.

OLIVEIRA JR., Wenceslao Machado de. Grafar o espaço, educar os olhos. Rumo a geografias menores. Revista Pro-Posições, Campinas/SP, v. 20, n. 3 (60), p. 17-28, 2009.

OLIVEIRA JR., Wenceslao Machado de. Mapas em deriva: imaginação e cartografia escolar. Revista Geografares, n. 12, p. 1-49, 2012. Disponível em: < http://periodicos.ufes.br/geografares/article/view/3187>. Acesso em: 29 maio 2016.

OLIVEIRA JR., Wenceslao Machado de. Vídeos, resistências e geografias menores. Linguagens e maneiras contemporâneas de resistir. Revista Terra Livre, São Paulo/SP, ano 26, v. 1, n. 34, p. 161-176, 2010. 
PANOFSKY, Erwin. Studies in Iconology: Humanistic Themes in the Art of the Renaissance. Westview Press, 1972.

PECKHAM, Robert Shannan. Landscape in Film. In: DUNCAN, James S.; JOHNSON, Nuala C. \& SCHEIN, Richard H. A companion to cultural geography. Blackwell Publishing, 2004.

UNO, Kuniichi. A gênese de um corpo desconhecido. São Paulo: n.1 Edições, 2012.

ROOS, Djeovani \& FERRAZ, Cláudio Benito O. Tramas do vídeo: leituras geográficas a partir das imagens videográficas. In: CONGRESSO BRASILEIRO DE GEÓGRAFOS (VII CBG), 7., 2014, Vitória. Anais eletrônicos do VII Congresso Brasileiro de Geógrafos. Vitória/ES: Associação dos Geógrafos Brasileiros - AGB, 2014. Disponível em: $<$ http://www.cbg2014.agb.org.br/resources/anais/1/1403322543 ARQUIVO ARTI GO CBG-2014.pdf>. Acesso em: 21 de Junho de 2016.

SANTOS, Douglas. A reinvenção do espaço: diálogos em torno da construção do significado de uma categoria. São Paulo: Ed. da UNESP, 2002.

SANTOS, Douglas. O que é geografia?. Texto inédito, 2007.

SANTOS, Douglas. Entrevista. Entre-Lugar. Revista do Programa de Pós-Graduação em Geografia da UFGD - Universidade Federal da Grande Dourados, Dourados/MS: UFGD, ano 1, n. 2, p. 183-193, jul./dez. 2010. Disponível em: <https://goo.gl/ba73Ge>. Acesso em: 19 jun. 2016.

SANTOS, Fátima C. dos. Por uma escuta nômade: a música dos sons da rua. São Paulo/SP: EDUC - FAPESP, 2004.

TRINDADE, Rafael. Deleuze: rizoma. Disponível em: $<$ http://arazaoinadequada.wordpress.com/2013/09/21/deleuze-rizoma >. Acesso em: 19 jun. 2016.

VASCONCELlOS, Jorge. Deleuze e o cinema. Rio de Janeiro/RJ: Ciência Moderna, 2006. 